
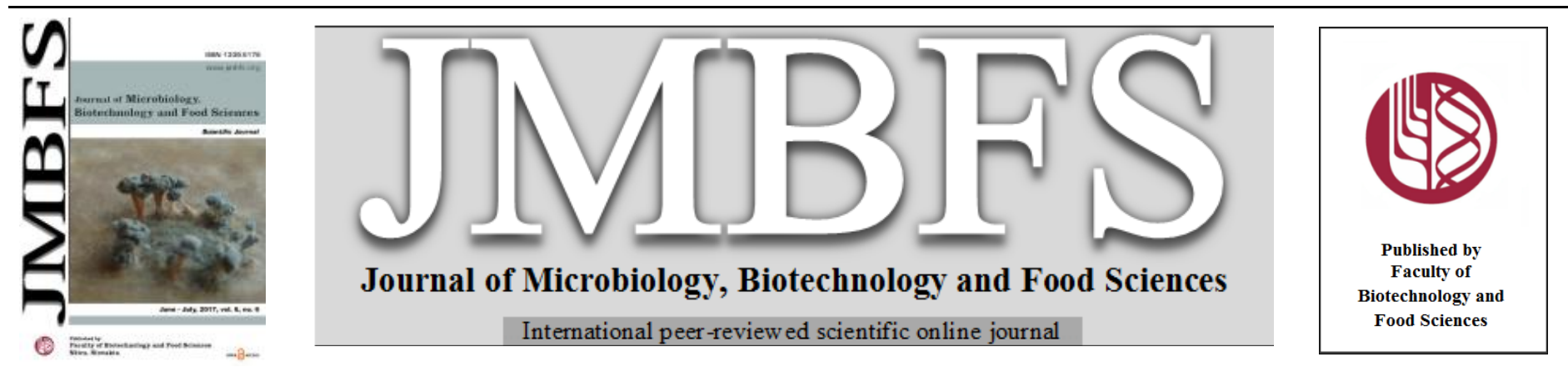

\title{
EFFECT OF POMEGRANATE PEEL POWDER ON THE HYGIENIC QUALITY OF BEEF SAUSAGE
}

\section{Ebied, A. Saleh ${ }^{1}$, Alaa Eldin M. Morshdy ${ }^{2}$, Abd-El-Salam E. Hafez ${ }^{2}$, Mohamed A. Hussein ${ }^{2}$,Eman S. Elewa ${ }^{2}$, and Abdallah Fikry A. Mahmoud $^{2 *}$}

\author{
$\operatorname{Address(es):~}$ \\ ${ }^{1}$ Food Control Department, Faculty of Veterinary Medicine, Damanhour University, Egypt. \\ ${ }^{2}$ Food Control Department, Faculty of Veterinary Medicine, Zagazig University, Zagazig 44519, Egypt.
}

*Corresponding author: abdallah.fikry90@gmail.com

doi: $10.15414 /$ jmbfs.2017.6.6.1300-1304

\section{ARTICLE INFO}

Received 19. 4. 2017

Revised 30. 4. 2017

Accepted 13. 5. 2017

Published 1. 6. 2017

Regular article

open $\bigodot_{\text {access }}$

\begin{abstract}
Pomegranate (Punica granatum) peel is a nutrient-rich byproduct whose production are extensively growing due to the exponential rise in the pomegranate juice production. Pomegranate juice and related products are directly added to foods due to their pleasant taste, palatability, and preservative effects. In this study, the effect of pomegranate peel powder was investigated at a concentration of $2.5 \%$ and $5 \%$ on beef sausage stored at $-18 \pm 2{ }^{\circ} \mathrm{C}$. A significant effect on $\mathrm{pH}$ was detected at zero time where control, $2.5 \%$ and $5 \%$ had $\mathrm{pH}$ values of $6.18 \pm 0.14,5.87 \pm 0.13$ and $5.54 \pm 0.17$, respectively. Meanwhile, the significant effect of pomegranate peel powder on total volatile nitrogen (TVN) and thiobarbituric acid (TBA) appeared on $4^{\text {th }}$ week. Total bacterial counts (TBC) and Enterobacteriaceae counts were reduced significantly on $1^{\text {st }}$ and $3^{\text {rd }}$ weeks in examined samples of different groups. Thus, in general, it can be concluded that addition of pomegranate peel powder is an effective tool to decrement $\mathrm{pH}, \mathrm{TVB}-\mathrm{N}$, TBA and bacterial counts in oriental sausage.
\end{abstract}

Keywords: Beef sausage, Aerobic plate count, Enterobacteriaceae, TBA, TVB-N

\section{INTRODUCTION}

Sausages are comminuted processed meat products prepared from red meat, poultry or a combination of these with water, binders and seasoning. They are commonly stuffed into a casing, and may be cured, smoked or cooked. Sausages as one of the oldest varieties of meat processing in which meats go through various modification processes to acquire desirable organoleptic and keeping properties. The Sausage manufacture is a simple procedure of allowing meat to undergo series of controlled structural and chemical changes. These are basic to all cultures but the changes rely on varied methods of preparation and seasoning to achieve desired distinctive characteristics. Even though the size and scope of operation have experienced a remarkable level of change the principles and idea behind modern day sausage manufacture in achieving products of high organoleptic value and improved shelf life remain the same (Savić, 1985). Pomegranate (Punica granatum) from the Punicaceae family is an importan commercial fruit crop that is extensively cultivated in parts of Asia, North Africa, the Mediterranean and the Middle East. Some studies have reported that differen parts of the pomegranate fruit such as juice, peel, and seeds may act as potential antimicrobial agents (Duman et al., 2009; Abdollahzadeh et al., 2011; Choi et al., 2011; Singh et al., 2014). Recently, higher antimicrobial and antioxidant activities of pomegranate peel extracts have been reported and therefore might be suggested as a safe natural option to synthetic antimicrobial agents (RosasBurgos et al., 2017). Additionally, the pomegranate peel extract showed the highest punicalagin and ellagic acid concentrations that have been identified as the principal factor behind the pomegranate antimicrobial activity. On the other hand, the antioxidant activity of pomegranate juice is higher than other fruit juices (Seeram et al., 2008). This antioxidant activity has been correlated to the highest content of phenolic compounds, including anthocyanins (3-glucosides and 3,5-diglucosides of delphinidin, cyanidin, and pelargonidin), ellagic acid, punicalin, punicalagin, pedunculagin and different flavonoids. Pomegranate rind is an inedible part obtained during the processing of pomegranate juice. Lately, the use of pomegranate juice and rind powder as a source of natural antioxidant in chicken patties had been investigated (Naveena et al., 2008). Furthermore, Devatkal et al. (2010) have shown a significant antioxidant effect of extracts of pomegranate rind and seed powders. Therefore, the aim of our work was to improve the hygienic quality of the sausage by the increase of different concentrations of pomegranate peel powder.

\section{MATERIALS AND METHODS}

\section{Preparation of beef sausage}

Beef meat samples including boneless neck, chuck and rounds along with associated fats were obtained from local markets at Zagazig city, Egypt, and used for preparing beef sausage samples. All sub cut fat and inter-muscular fat were included as fat sources. The beef meat and fat tissue were transported to the laboratory using an icebox. Different ingredients used in preparing beef sausage samples e.g. table salt, starch and spices mixture such as black pepper, red pepper, nutmeg and ginger were obtained from local markets at Zagazig, Egypt. Beef sausage samples were made according to the method described by Zaika $\boldsymbol{e t}$ al. (1978). Meat and fat tissues were cut into small portions (approximately $6 \mathrm{~cm}$ long, $5 \mathrm{~cm}$ wide, and $4 \mathrm{~cm}$ thick). These cuts were ground to particles of about a rice size $(2 \mathrm{~mm} \times 4 \mathrm{~mm})$, then the ingredients were blended to prepare sausage mixture emulsion, which was then stuffed by sausage filling machine previously washed by hot water and cased in mutton casings. Three groups of sausage were prepared, including control group, Group 1 and 2. The Control group consists of lean meat $70 \%$, fat $12 \%$, sodium chloride $2.3 \%$, water $9.3 \%$, garlic $1 \%$, onion $1.2 \%$ and spices mixture $1.2 \%$ ). The group 1 (G1) was similar to the control but after mixing $2.5 \%$ removed and replaced with $2.5 \%$ dried pomegranate peel powder then mixed again), meanwhile group 2 (G2), after mixing 5\% removed and replaced with $5 \%$ dried pomegranate peel powder then mixed again). Finally, the prepared sausage samples were stored at $-18 \pm 2{ }^{\circ} \mathrm{C}$ in order to simulate the normal storage temperature used in the retail sausage outlets present in Egypt.

\section{Chemical analyses}

The determination of the $\mathrm{pH}$ values of different beef sausage samples were done according to the method described by Defreitas et al. (1997) as follows; a known weight of beef sausage sample $(30 \mathrm{~g})$ was blended with $100 \mathrm{ml}$ distilled water and the $\mathrm{pH}$ of the slurry was then measured using a $\mathrm{pH}$ meter (HANNA Instrument, USA). On the other hand, determination of total volatile basic nitrogen (TVB-N) was carried out according to Conway's micro diffusion technique recommended by (FAO, 1992). However, determination of thiobarbituric acid (TBA) was performed according to (Kirk and Sawyer, 1991). 
Bacteriological analyses

\section{Preparation of samples for bacteriological examination}

Sausage samples were prepared for microbiological analysis in accordance with ISO 6887-1(2003). For the Aerobic plate count (Baumgart \& Firnhaber, 1986); One $\mathrm{ml}$ of each previously prepared serial dilution was carefully transferred into separate, duplicate, appropriately marked Petri dishes, and thoroughly mixed with about $15 \mathrm{ml}$ of previously melted and adjusted $\left(45 \pm 1^{\circ} \mathrm{C}\right)$ plate count agar (Oxiod, CM325). After solidification, the inoculated plates as well as control one were inverted and incubated promptly for $48 \pm 2 \mathrm{~h}$ at $37^{\circ} \mathrm{C}$ The countable plates with 30-300 colonies were recorded and the total colony count per $\mathrm{cm}^{2}$ was calculated. However, for the enumeration of Enterobacteriaceae (ICMSF, 1978); $0.1 \mathrm{ml}$ from the original and the subsequent prepared dilutions were spread on surface of Petri dish in duplicate plates containing Violet red bile glucose agar (VRBGA), and incubated at $37^{\circ} \mathrm{C}$ for 24 hours. All large purple colonies were counted and the average number of Enterobacteriaceae per gram of sample was calculated and recorded.

\section{RESULTS AND DISCUSSION}

Effect of pomegranate peel powder on $\mathrm{pH}$ during freezing at $-18 \pm 2^{\circ} \mathrm{C}$

The $\mathrm{pH}$ value is the important physicochemical characteristic to decide the quality and shelf life of sausage. The $\mathrm{pH}$ value of control, 2.5 and 5\% pomegranate treated sausage at zero time was $6.18 \pm 0.14,5.87 \pm 0.13$ and $5.54 \pm$ 0.17 , respectively. There were significant effects $(\mathrm{p}<0.05)$ of both treatments as compared to control samples. This direct effect related to the acidic $\mathrm{pH}$ of pomegranate peel powder $(\mathrm{pH}=3.75)$ as recorded by (Ullah et al., 2012). Our results were in disagreement with El-Nashi $\boldsymbol{e t}$ al. (2015) who found that no significant differences in $\mathrm{pH}$ values of different prepared beef sausage samples containing $0 \%, 1 \%, 2 \%$ and $3 \%$ of pomegranate peels powder. After elapsing of 8 weeks of storage at $-18 \pm 2{ }^{\circ} \mathrm{C}$ the mean value of $\mathrm{pH}$ was $6.27 \pm 0.16,5.9 \pm$ 0.15 and $5.73 \pm 0.19$ for control, 2.5 and $5 \%$ pomegranate treated sausage, respectively. Results shown in the figure (1) indicated that freezing had no effect on $\mathrm{pH}$ value of the same group during storage weeks. The obtained results were corresponded with Muela $\boldsymbol{e t}$ al. (2010) who suggested that the $\mathrm{pH}$ of fresh meat and frozen meat did not differ significantly. On contrary, Kim and Lee (2011) reported that frozen meat had a higher $\mathrm{pH}$ than fresh meat because of partial denaturation of the muscle proteins.

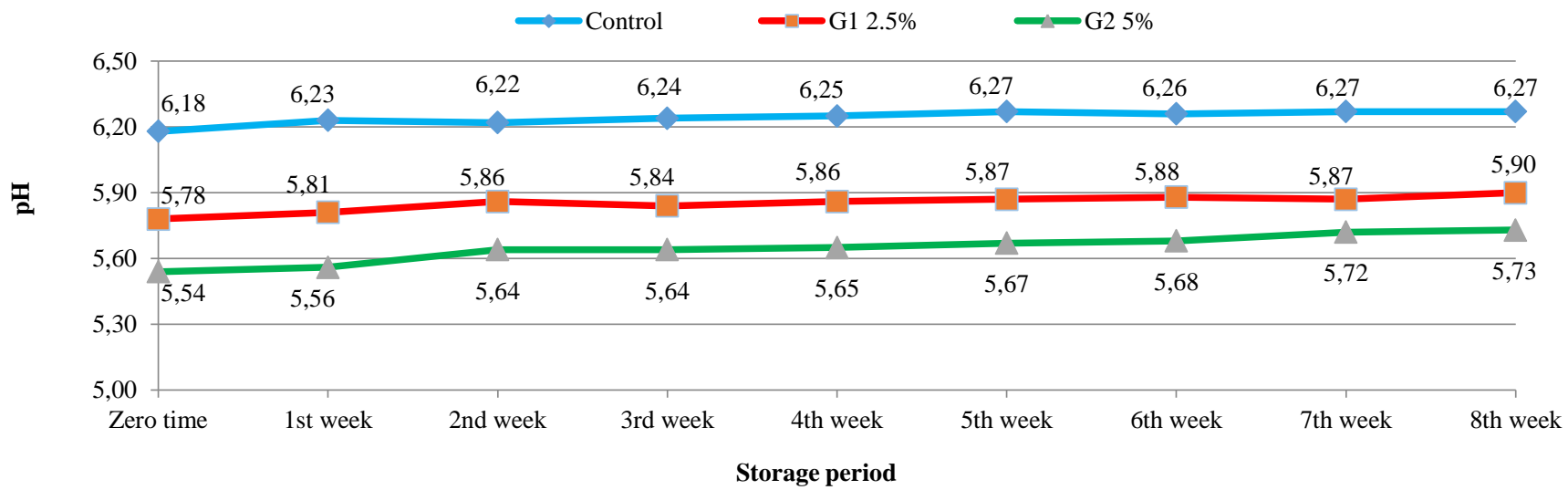

Figure $1 \mathrm{pH}$ values in control and pomegranate treated groups $(\mathrm{G} 1,2.5 \%)$ and $(\mathrm{G} 2,5 \%)$ during freezing at $-18 \pm 2{ }^{\circ} \mathrm{C}$

$2.5 \%$ and $5 \%$ pomegranate peel powder treated groups, respectively. By the $8^{\text {th }}$ week, TVN values were $20.04 \pm 4.10,16.00 \pm 3.45$ and $14.33 \pm 4.21 \mathrm{mg} / 100 \mathrm{~g}$

Effect of pomegranate peel powder on total volatile nitrogen during freezing at $-18 \pm 2^{\circ} \mathrm{C}$ for control, $2.5 \%$ and $5 \%$ pomegranate peel powder treated groups, respectively. There were significant effects $(\mathrm{p}<0.05)$ of pomegranate peel powder added at concentration of 2.5 and $5 \%$ after four and eight weeks of freezing at $-18 \pm 2{ }^{\circ} \mathrm{C}$ The increasing of TVN during freezing weeks was attributed to the continuous enzyme activity (Berry $\boldsymbol{e t}$ al., 2008). The obtained results were concurred with that obtained by Ibrahim (2004). Additionally, the total volatile nitrogen values of all treatments were in the range of permissible level $(<20 \mathrm{mg} / 100 \mathrm{~g})$ the results achieved in table (1), it could be noticed that total nitrogen (TVN) of control, $2.5 \%$ and $5 \%$ pomegranate peel powder (PGPP) treated groups was $6.50 \pm 1.23,6.41 \pm 1.23$ and $6.39 \pm 1.23 \mathrm{mg} / 100 \mathrm{~g}$ respectively at zero time. There were no significant effects of pomegranate pee powder (PGPP) at zero time. The TVN values increased gradually with increasing frozen storage period. After elapsing of four weeks the recorded established by Egyptian standard specifications (ESS, 2005) values were $16.00 \pm 1.70,11.00 \pm 1.41$ and $9.23 \pm 1.12 \mathrm{mg} / 100 \mathrm{~g}$ for control,

Table 1 Total volatile basic nitrogen (TVB-N) mg/100g in control and treated sausage during freezing at $-18 \pm 2{ }^{\circ} \mathrm{C}$

\begin{tabular}{|c|c|c|c|c|c|c|c|c|c|c|c|c|}
\hline \multirow{2}{*}{ Period } & \multicolumn{4}{|c|}{ Control group } & \multicolumn{4}{|c|}{ Treated group(G1) with $2.5 \%$} & \multicolumn{4}{|c|}{ Treated group(G2) with $5 \%$} \\
\hline & Min & $\operatorname{Max}$ & Mean & SD & Min & $\operatorname{Max}$ & Mean & SD & Min & $\operatorname{Max}$ & Mean & SD \\
\hline Zero time & 5.40 & 7.80 & $6.50^{\mathrm{Ac}}$ & 1.23 & 5.40 & 7.80 & $6.41^{\mathrm{Ac}}$ & 1.23 & 5.40 & 7.80 & $6.39^{\mathrm{Ac}}$ & 1.23 \\
\hline $4^{\text {th }}$ week & 12.00 & 19.20 & $16.00^{\mathrm{Ab}}$ & 1.70 & 8.00 & 13.10 & $11.00^{\mathrm{Bb}}$ & 1.41 & 7.40 & 11.20 & $9.23^{\mathrm{Bb}}$ & 1.12 \\
\hline $8^{\text {th }}$ week & 13.20 & 23.20 & $20.04^{\mathrm{Aa}}$ & 4.10 & 11.23 & 19.30 & $16.00^{\mathrm{Ba}}$ & 3.45 & 9.47 & 17.36 & $14.33^{\mathrm{Ca}}$ & 4.21 \\
\hline
\end{tabular}

Means carrying different superscript capital letters on the same column are significantly different $(\mathrm{P}<0.05)$ on different group

Means carrying different superscript small letters on the same row are significantly different $(\mathrm{P}<0.05)$ on same group.

Effect of pomegranate peel powder on thiobarbituric acid (TBA) during freezing at $-18 \pm 2^{\circ} \mathrm{C}$

As shown in table (2), the level of thiobarbituric acid of all treatments at zero time of control, $2.5 \%$ and $5 \%$ pomegranate powder treated groups was $0.27 \pm$ $0.11 \mathrm{mg}$ malonaldhyde/kg. There were no significant effects $(\mathrm{p}>0.05)$ at zero time. As the frozen storage time progressed, the thiobarbituric acid values of all treatments increased gradually. However, the lowest TBA value was recorded for sausage contained $5 \%$ pomegranate peel powder, meanwhile the highest increment of TBA value was noted for control sausage which reached $0.84 \mathrm{mg}$ malonaldhyde/kg after 8 weeks from the start of freezing storage $\left(-18^{\circ} \mathrm{C}\right)$ Generally, the increases of TBA values that observed in all sausages treatments contained pomegranate peel powder were less than that found in the control sausage that might be explained by the ability of pomegranate peel powder to scavenge free radicals, and its antioxidant power (Gil et $\boldsymbol{a l} ., \mathbf{2 0 0 0}$ ). TBA values of all samples after the eight weeks of storage were within the range of permissible level ( $<0.9 \mathrm{mg}$ malonaldhyde/ $\mathrm{kg}$ for frozen sausage) set by Egyptian standard specifications (ESS, 2005) 
Table 2 Thiobarbituric acid (TBA) $\mathrm{mg}$ malondialdehyde/kg in control and treated sausage during freezing at $-18 \pm 2{ }^{\circ} \mathrm{C}$

\begin{tabular}{|c|c|c|c|c|c|c|c|c|c|c|c|c|}
\hline \multirow{2}{*}{ Period } & \multicolumn{4}{|c|}{ Control group } & \multicolumn{4}{|c|}{ Treated group(G1) with $2.5 \%$} & \multicolumn{4}{|c|}{ Treated group (G2) with $5 \%$} \\
\hline & Min & Max & Mean & SD & Min & Max & Mean & SD & Min & $\operatorname{Max}$ & Mean & SD \\
\hline Zero time & 0.21 & 0.39 & $0.27^{\mathrm{Ac}}$ & 0.11 & 0.21 & 0.39 & $0.27^{\mathrm{Ac}}$ & 0.11 & 0.21 & 0.39 & $0.27^{\mathrm{Ac}}$ & 0.11 \\
\hline $4^{\text {th }}$ week & 0.56 & 0.79 & $0.62^{\mathrm{Ab}}$ & 0.15 & 0.35 & 0.54 & $0.46^{\mathrm{Bb}}$ & 0.08 & 0.28 & 0.49 & $0.39^{\mathrm{Bb}}$ & 0.10 \\
\hline $8^{\text {th }}$ week & 0.82 & 0.87 & $0.84^{\mathrm{Aa}}$ & 0.09 & 0.48 & 0.67 & $0.59^{\mathrm{Ba}}$ & 0.10 & 0.38 & 0.49 & $0.42^{\mathrm{Ca}}$ & 0.13 \\
\hline
\end{tabular}

Means carrying different superscript capital letters on the same column are significantly different $(\mathrm{P}<0.05)$ on different group.

Means carrying different superscript small letters on the same row are significantly different $(\mathrm{P}<0.05)$ on same group.

Effect of pomegranate peel powder on aerobic plate count (APC) during freezing at $-18 \pm 2^{\circ} \mathrm{C}$

The data presented in figure (2) showed that the mean value of APC at zero time of control, $2.5 \%$ and $5 \%$ pomegranate treated groups was $5.65 \pm 1.38,5.59 \pm 1.92$ and $5.59 \pm 1.92 \log _{10} \mathrm{CFU} / \mathrm{g}$, respectively. There were no significant effects related to the addition of pomegranate peel powder of different prepared beef sausage at zero time. The obtained data revealed that beef sausage samples treated with $2.5 \%$ and $5 \%$ concentrations of pomegranate peels powder, had a significant reduction on APC at $2^{\text {nd }}$ and $3^{\text {rd }}$ week, respectively. APC of prepared beef sausage (control, $2.5 \%$ and $5 \%$ pomegranate treated groups) was progressively reduced to $4.85 \pm 0.64,4.39 \pm 0.51$ and $4.10 \pm 0.42 \log _{10} \mathrm{CFU} / \mathrm{g}$, respectively over the time of storage period. Moreover, the results showed a significant reduction at the $8^{\text {th }}$ week $(\mathrm{p}<0.05)$ in both 2.5 and $5 \%$ pomegranate powder treated sausage. These results could be due to the antimicrobial effect of pomegranate peels powder especially when the concentration of pomegranate peels powder was increased. According to Rosas-Burgos et al. (2017), the pee of the pomegranate fruits is a rich source of antifungal and antibacterial compounds such as ellagic acid and punicalagins $(\alpha$ and $\beta)$, and this might be employed as a natural alternative to synthetic antimicrobial agents. The observed results seemed to be similar to the results of El-Nashi et al. (2015), Agourram et al. (2013), Kanatt et al. (2010) and Al-Zoreky (2009) who evaluated the antimicrobial characteristics of pomegranate peels. They found that pomegranate peels have an inhibition effect against gram positive and gram-negative bacteria A gradual decrease was observed in APC of control beef sausage samples during the storage period. The count became $4.85 \pm 0.64 \log _{10} \mathrm{CFU} / \mathrm{g}$ at the end of storage period. On the other hand, the pomegranate $2.5 \%$ and $5 \%$ treated groups had the same pattern of the gradual decrease and became $4.39 \pm 0.51$ and $4.10 \pm$ $0.42 \log _{10}$ CFU/g, respectively. The significant effect of freezing on reduction of APC appeared on control and pomegranate treated sausage in the $3^{\text {rd }}$ and $5^{\text {th }}$ week, respectively. Our results accorded with (Ray and Bhunia, 2007) who found that maximum lethality is seen with slow freezing where exposure to high concentrations is prolonged. Survival is greater with rapid freezing where exposure to these conditions is minimized. However, food-freezing processes are not designed to maximize microbial lethality but to minimize loss of product quality.

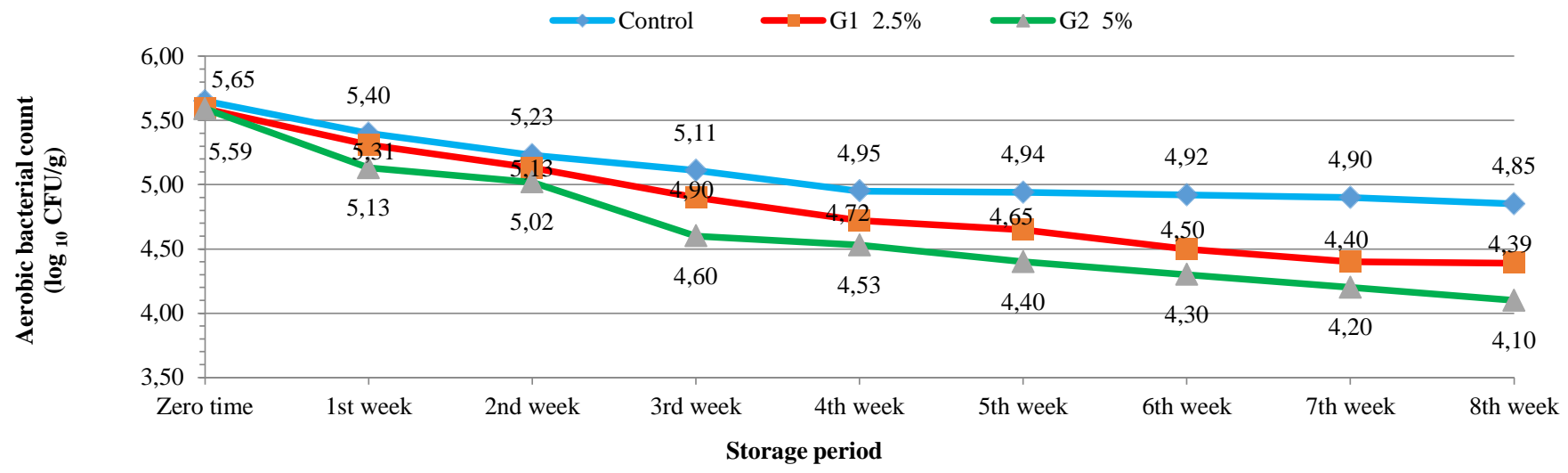

Figure 2 Aerobic bacterial counts $\left(\log { }_{10} \mathrm{CFU} / \mathrm{g}\right)$ in control and pomegranate treated groups $(\mathrm{G} 1,2.5 \%)$ and $(\mathrm{G} 2,5 \%)$ frozen at $-18 \pm 2{ }^{\circ} \mathrm{C}$

Effect of pomegranate peel powder on Enterobacteriaceae count during freezing at $-18 \pm 2^{\circ} \mathrm{C}$

The data presented in figure (3) showed that the mean values of Enterobacteriaceae count at zero time of control, $2.5 \%$ and $5 \%$ treated groups were $3.18 \pm 1.13,3.12 \pm 1.19$ and $3.09 \pm 0.98 \log _{10} \mathrm{CFU} / \mathrm{g}$, respectively. No significant effects related to the addition of pomegranate peel powder to the prepared beef sausage were detected at zero time. The obtained data revealed that, the beef sausage samples treated with different concentrations of pomegranate peels powder $(2.5 \%$ and $5 \%)$ led to a significant reduction of Enterobacteriaceae count at $3^{\text {rd }}$ week. Progressive reduction of the Enterobacteriaceae count over the time of storage period; whereas, in $8^{\text {th }}$ week, the Enterobacteriaceae count of the control group, $2.5 \%$ and $5 \%$ of treated groups reached to $2.95 \pm 0.65,2.28 \pm 0.87$ and $2.20 \pm 0.98 \log _{10} \mathrm{CFU} / \mathrm{g}$ respectively. Moreover, there were a significant effect at the $8^{\text {th }}$ week $(\mathrm{p}<0.05)$ in both 2.5 and $5 \%$ pomegranate powder treated groups. The obtained results may be attributed to the antimicrobial effect of pomegranate peels. According to Li et al. (2006), pomegranate peel powder is an important source of bioactive compounds such as phenolic compounds, which are secondary plant metabolites and possess antibacterial or antiviral activities (Cai et al., 2004). The significant effect of freezing on reduction of Enterobacteriaceae appeared in control and pomegranate treated sausage in the $4^{\text {th }}$ and $5^{\text {th }}$ weeks, respectively. Furthermore, the freezing effect pronounced on Enterobacteriaceae count, where cold shock affect gram-negative bacteria than gram positive (Dodd et al., 2007). 


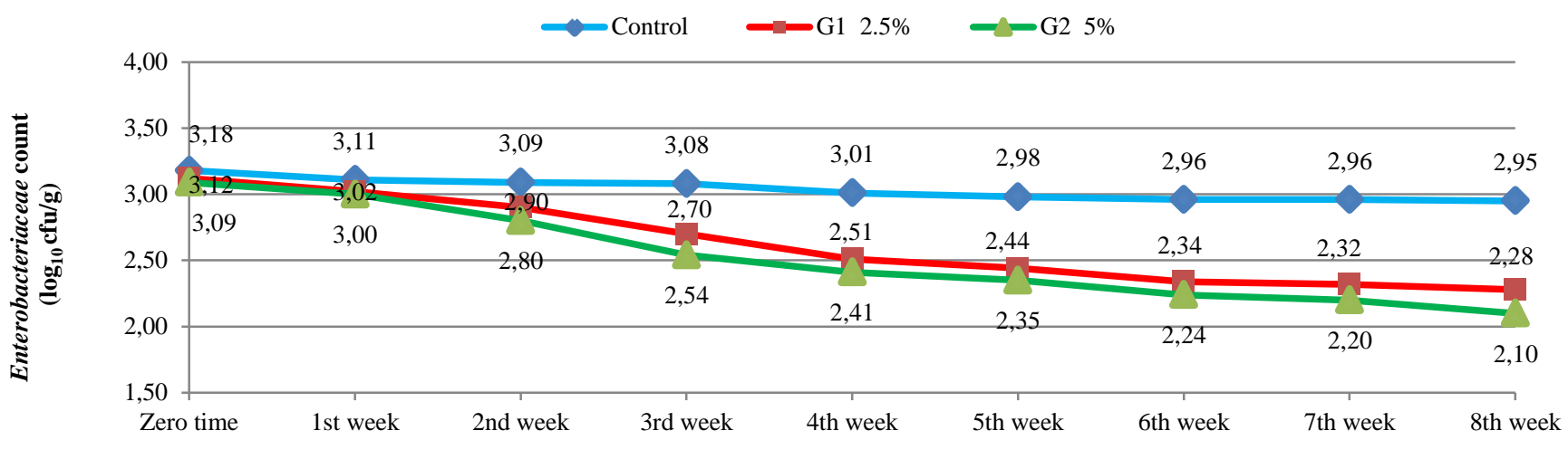

Storage period

Figure 3 Enterobacteriaceae count $\left(\log _{10} \mathrm{CFU} / \mathrm{g}\right)$ in control and treated groups $(\mathrm{G} 1,2.5 \%)$ and $(\mathrm{G} 2,5 \%)$ frozen at $-18 \pm 2{ }^{\circ} \mathrm{C}$

\section{CONCLUSION}

The aim of the presented study was to evaluate the impact of pomegranate peel powder $(2.5 \%$ and $5 \%)$ on beef sausage stored at $-18 \pm 2{ }^{\circ} \mathrm{C}$. It was found that pomegranate peel powder had a substantial effect on $\mathrm{pH}$, total volatile nitrogen (TVN) and thiobarbituric acid (TBA) over the storage period compared to the control group. Moreover, the total bacterial counts (TBC) and Enterobacteriaceae counts were reduced significantly in the pomegranate treated group. Therefore, the use of pomegranate peel powder is considered as effective food additive to decrement $\mathrm{pH}, \mathrm{TVB}-\mathrm{N}, \mathrm{TBA}$ and bacterial counts in sausage Further future studies are necessary to measure the color and organoleptic attributes of the sausages, in addition, the application of pomegranate pee powder alone or in combination with other antibacterial agents such as essential oils, organic acid salts to control foodborne pathogens in different food products.

Acknowledgements: The authors are grateful for financial support from the Ministry of Higher Education and Scientific Research (MHESR), Egypt.

\section{REFERENCES}

Abdollahzadeh, S., Mashouf, R., Mortazavi, H., Moghaddam, M., Roozbahani, N., \& Vahedi, M. (2011). Antibacterial and antifungal activities of punica granatum peel extracts against oral pathogens. Journal of Dentistry (Tehran), $8(1), 1-6$.

Agourram, A., Ghirardello, D., Rantsiou, K., Zeppa, G., Belviso, S., Romane, A., \& Giordano, M. (2013). Phenolic Content, Antioxidant Potential, and Antimicrobial Activities of Fruit and Vegetable By-Product Extracts. International Journal of Food Properties, 16(5), 1092-1104. https://doi.org/10.1080/10942912.2011.576446

Al-Zoreky, N. S. (2009). Antimicrobial activity of pomegranate (Punica granatum L.) fruit peels. International Journal of Food Microbiology, 134(3), 244-248. https://doi.org/10.1016/j.ijfoodmicro.2009.07.002

Baumgart, J., \& Firnhaber, J. (1986). Mikrobiologische untersuchung von lebensmitteln.

Berry, M., Fletcher, J., McClure, P., \& Wilkinson, J. (2008). 2 Effects of Freezing on Nutritional and Microbiological Properties of Foods. Frozen Food Science and Technology, 26.

Cai, Y., Luo, Q., Sun, M., \& Corke, H. (2004). Antioxidant activity and phenolic compounds of 112 traditional Chinese medicinal plants associated with anticancer. Life $\quad$ Sciences, 74(17), 2157-2184 https://doi.org/10.1016/j.lfs.2003.09.047

Choi, J. G., Kang, O. H., Lee, Y. S., Chae, H. S., Oh, Y. C., Brice, O. O., ... \& Kwon, D. Y. (2011). In Vitro and In Vivo Antibacterial Activity of Punica granatum Peel Ethanol Extract against Salmonella. Evidence-Based Complementary and Alternative Medicine: eCAM, 2011, 1-8. https://doi.org/10.1093/ecam/nep105

DeFREITAS, Z., SEBRANEK, J. G., OLSON, D. G., \& CARR, J. M. (1997). Freeze/thaw Stability of Cooked Pork Sausages as Affected by Salt, Phosphate, $\mathrm{pH}$, and Carrageenan. Journal of Food Science, 62(3), 551-554. https://doi.org/10.1111/j.1365-2621.1997.tb04428.x

Devatkal, S. K., Narsaiah, K., \& Borah, A. (2010). Anti-oxidant effect of extracts of kinnow rind, pomegranate rind and seed powders in cooked goat meat patties Meat Science, 85(1), 155-159. https://doi.org/10.1016/j.meatsci.2009.12.019 Dodd, C. E. R., Richards, P. J., \& Aldsworth, T. G. (2007). Suicide through stress: A bacterial response to sub-lethal injury in the food environment International Journal of Food Microbiology, 120(1), 46-50. https://doi.org/10.1016/j.ijfoodmicro.2007.06.008

Duman, A. D., Ozgen, M., Dayisoylu, K. S., Erbil, N., \& Durgac, C. (2009) Antimicrobial activity of Six pomegranate (Punica granatum L.) varieties and their relation to some of their pomological and phytonutrient characteristics Molecules, 14(5), 1808-1817. https://doi.org/10.3390/molecules14051808

Egyptian Standard Specifications "ESS" (2005). Frozen sausage No. 1972 Egyptian Organization for Standardization and Quality Control, Ministry of Industry, Egypt.

El-Nashi, H. B., Abdel Fattah, A. F. A. K., Abdel Rahman, N. R., \& Abd ElRazik, M. M. (2015). Quality characteristics of beef sausage containing pomegranate peels during refrigerated storage. Annals of Agricultural Sciences, 60(2), 403-412. https://doi.org/10.1016/j.aoas.2015.10.002

FAO (1992). Food borne infection and intoxication in France organization 1991. D News Letter No. 38. WHO Surveillance programme for control of food borne infection and intoxicaiton in France.

Gil, M. I., Tomás-Barberán, F. A., Hess-Pierce, B., Holcroft, D. M., \& Kader, A A. (2000). Antioxidant activity of pomegranate juice and its relationship with phenolic composition and processing. Journal of Agricultural and Food chemistry, 48(10), 4581-4589. https://doi.org/10.1021/JF000404A

Ibrahim, M. M. M. (2004). Quality changes occurring during frozen storage of chicken sausage containing buffalo spleen. Egyptian Journal of Agricultural Research, 82(3), 327-342.

International Commission on Microbiological Specifications for Foods "ICMSF" (1978). Microorganisms in foods, 2. Sampling for microbiological analysis: principles and specifications for foods University: Toronto, Canada.

ISO 6887-1(2003). Microbiology of food and animal feeding stuffs -Preparation of test samples, initial suspension and decimal dilutions for microbiologica examination - Part 3: Specific rules for the preparation of fish and fishery products.

Kanatt, S. R., Chander, R. \& Sharma, A. (2010). Antioxidant and antimicrobial activity of pomegranate peel extract improves the shelf life of chicken products. International Journal of Food Science \& Technology, 45(2), 216-222. https://doi.org/10.1111/j.1365-2621.2009.02124.x

Kim, B.-S., \& Lee, Y.-E. (2011). Effect of Antioxidant on Quality of Ground Beef during the Refrigeration Storage. The Korean Journal of Food and Nutrition, 24(3), 422-433. https://doi.org/10.9799/ksfan.2011.24.3.422

Kirk, S., \& Sawyer, R. (1991): Pearson's composition and analysis of foods (No Ed. 9). Longman Group Ltd.

Li, Y., Guo, C., Yang, J., Wei, J., Xu, J., \& Cheng, S. (2006). Evaluation of antioxidant properties of pomegranate peel extract in comparison with pomegranate pulp extract. Food Chemistry, 96(2), 254-260. https://doi.org/10.1016/j.foodchem.2005.02.033

Muela, E., Sañudo, C., Campo, M. M., Medel, I., \& Beltrán, J. A. (2010). Effect of freezing method and frozen storage duration on instrumental quality of lamb throughout display. Meat Science, 84(4), 662-669. https://doi.org/10.1016/j.meatsci.2009.10.028

Naveena, B. M., Sen, A. R., Vaithiyanathan, S., Babji, Y., \& Kondaiah, N. (2008). Comparative efficacy of pomegranate juice, pomegranate rind powder extract and BHT as antioxidants in cooked chicken patties. Meat Science, 80(4) 1304-1308. https://doi.org/10.1016/j.meatsci.2008.06.005

Ray, B., \& Bhunia, A. (2007). Fundamental Food Microbiology, Fourth Edition CRC Press.

Rosas-Burgos, E. C., Burgos-Hernández, A., Noguera-Artiaga, L., Kačániová, M., Hernández-García, F., Cárdenas-López, J. L., \& Carbonell-Barrachina, Á. A (2017). Antimicrobial activity of pomegranate peel extracts as affected by cultivar. Journal of the Science of Food and Agriculture, 97(3), 802-810 https://doi.org/10.1002/jsfa.7799

Savić, I. V. (1985). Small-scale sausage production. Rome: Food and Agriculture Organization of the United Nations. Retrieved from http://www.fao.org/docrep/003/x6556e/X6556E00.htm

Seeram, N. P., Aviram, M., Zhang, Y., Henning, S. M., Feng, L., Dreher, M., \& Heber, D. (2008). Comparison of Antioxidant Potency of Commonly Consumed 
Polyphenol-Rich Beverages in the United States. Journal of Agricultural and Food Chemistry, 56(4), 1415-1422. https://doi.org/10.1021/jf073035s

Singh, M., Jha, A., Kumar, A., Hettiarachchy, N., Rai, A. K., \& Sharma, D. (2014). Influence of the solvents on the extraction of major phenolic compounds (punicalagin, ellagic acid and gallic acid) and their antioxidant activities in pomegranate aril. Journal of Food Science and Technology, 51(9), 2070-2077. https://doi.org/10.1007/s13197-014-1267-0

Ullah, N., Ali, J., Khan, A., Khurram, M., Hussain, A., Rahman, I. U., \& Shafqatullah, Z. U. R. (2012). Proximate Composition, Minerals Content, Antibacterial and antifungal Activity Evaluation of Pomegranate (Punica granatum L.) Peels Powder. Middle - East Journal of Scientific Research, 11(3), 396-401.

Zaika, L. L., Zell, T. E., Palumbo, S. A., \& Smith, J. L. (1978). Effect of spices and salt on fermentation of Lebanon bologna-type sausage. Journal of Food Science, 43(1), 186-189. https://doi.org/10.1111/j.1365-2621.1978.tb09766.x 